\title{
New Zealand Literature and the Global Marketplace
}

Paloma Fresno-Calleja* and Janet M. Wilson

University of Balearic Isles, Majorca, Spain; University of Northampton, UK

Email: paloma.fresno@uib.es

In the 2003, New Zealand literary critic Patrick Evans published a controversial and by now much-quoted essay entitled "Spectacular Babies: the Globalisation of New Zealand Fiction". ${ }^{1}$ This was a time that Evans saw as "epochal" for New Zealand literature in its transition from the postcolonial to the global (94). Two of the defining features of this moment, Evans argued, were "the professionalisation of the role of the author and the commodification of local fiction" (94), mostly as a result of the "growing dominance of the creative writing school in filtering, controlling and normalising the flow of writers into local publishing” (101). In his essay, Evans referred directly to Bill Manhire's hugely successful creative writing course at Victoria University of Wellington, which he described as "a conveyor belt which [...] offers a high-speed ride to exactly where any young writer would want to go" (96). Evans' main preoccupation was that these writers had left behind the nationalist or regionalist concerns which had historically characterized New Zealand writing, opting instead for "the removal or neutralizing of the New Zealand referent" (104) to accommodate global market requirements.

This special issue revisits some of the discussions which Evans brought up 20 years ago to explore a range of writing, performing, publishing, teaching and marketing practices and strategies. ${ }^{2}$ The overall aim is to reflect on the extent to which national and regional labels, essential to the definition and development of Aotearoa New Zealand's identity and cultural expression in the colonial and postcolonial periods, are 
being discarded by authors, critics or publishers to benefit from the cultural flows channeled through diaspora, globalization and transnationalism, or on the contrary are being reformulated in order to resist or negotiate the commodifying impositions of the global literary marketplace. The contributions in this issue revolve around "New Zealand literature" as a body of writing once perceived as unitary in purpose and more or less coherent in orientation, which John Newton has recently pronounced "a finite chapter, complete and increasingly remote" $(2017,11)$ and which, in his view, is “effectively "dead"” (9).

Adopting a less fatalistic position, but reiterating some of Evans' arguments, Witi Ihimaera's 2015 lecture for the New Zealand Book Council, "Where is New Zealand Literature Heading?", concludes that "New Zealand literature still exists - but [ $\ldots$ ] it is not New Zealand literature as you and I know it" $(2015,30)$. Ihimaera talks of the two imperatives historically determining New Zealand writing: the nationalist and the individualist (9-10), arguing that until the 1990s "the main business of both imperatives was the production of a national literature about New Zealand and our identity as New Zealanders" (12). Ihimaera acknowledges that the country's literature has now entered a new phase in which writers do not feel constrained by former imperatives and have learned to thrive in a world dominated by "the great Amazon order of things" (23); but he nostalgically resents that "the great, dissident New Zealand voice" (21) is missing from most of this literature. Even Māori writers, he adds, are writing differently from the previous generations, telling stories "about who they are rather than what they are" (29). Ihimaera shows his reluctance to "give up on that grand New Zealand project" (25) and produce writing "based on our region's history and for our region's people" (26). This is particularly urgent for Māori writers who, Ihimaera concludes, cannot "afford to burn the Māori nationalistic bridges" (29). 
Postcolonial and diaspora theories have for long addressed the inadequacies of national labels, proposing alternative transnational, diasporic or cosmopolitan approaches to the literatures of formerly colonized countries (Bhabha 1990, 1994; Gilroy 1993; Brah 1997; Cheah and Robbins 1998; Quayson and Daswani 2013). Global literary studies have also offered a sustained challenge to the national model, particularly through theoretical articulations of the concept of "world literature" (Moretti 2000; Damrosch 2003; Casanova 2004). These definitions largely consider the processes that affect a literary work when transported "beyond its linguistic and cultural point of origin" (Damrosch 2003, 6), and focus on its status as "an object of circulation in a global market of print commodities or as the product of a global system of production" (Cheah 2016, 24). Is the redefinition of "New Zealand literature" as "world literature" a valid way to liberate it from its cultural straightjacket or does such a definition blur its supposed specificity and postcolonial impact, actually continuing to perpetuate the notions of remoteness and insignificance against which New Zealanders have historically struggled? Do New Zealand books, asks writer Paula Morris (2016), really "need special treatment"? Do they need to be placed on "the New Zealand table" to achieve recognition and acquire a distinctive market value, or should New Zealand writers "stand upright and clamber onto the shelves where we belong, alongside the other writers of the world"? Does this post-national and globalized bookshelf allow for an equal space of "maximal and convivial diversity" or is this worlding process in fact "the final and devastating triumph of the homogenizing forces of modernity" (Helgesson and Vermeulen 2016, 4)?

Although, as Robert Young (2012) contends, postcolonial and world literature studies continue to occupy apparently irreconcilable critical positions as a result of their different degrees of engagement with their own cultural contexts (221), recent critical 
efforts have in fact placed them in dialogue with each other. In that respect, Stephan Helgesson (2014) proposes "a combination of postcolonial and world literature methodologies that may account for literature both as grounded in local, conflictual histories and as a circulational phenomenon that moves across languages and literary fields" (484); literature, he points out, experiences the demands and pressures of the global market, but can also benefit from these global forces by creating "a world of its own and an enabling alternative to other domains of power" (484). Along the same lines, Pheng Cheah (2016) proposes a "radical rethinking of world literature as literature that is an active power in the making of worlds, that is, both a site of processes of worlding and an agent that participates in these processes" (2). Departing from Goethe's original formulation of Weltliteratur, Bill Ashcroft reminds us that "the world of world literature [is] less a set of works, than a network" $(2013,34)$ and suggests that postcolonial literature is a paradigmatic example of a "system of world literature" as writers "made use of the economic network of imperial relations to enter the world" and can continue to transform "the various dominating discourses of imperial control" (35), now evident in the workings of a literary marketplace managed from western metropolitan centres.

For all the impact and currency of global approaches, and as Ashcroft (2013) argues for the Australian case, "world literature still seems unable to challenge the importance of the nation in the institution of literature and literary study" (34). In contexts like Australia and New Zealand, which continue to struggle with a colonial legacy marked by injustice, inequality and indigenous oppression, and have historically carried the burden of a cultural cringe in relation to Europe, turning away from a distinctive national definition comes with some resistance. As Lydia Wevers (2004) contends, "the symbolic investment represented by cultural production is much more 
crucial to a small, fragile and historically short-term national culture than to a larger one" (118); this would explain why New Zealand writers have been forced to answer certain questions regarding their creative choices which would simply not be asked elsewhere.

Historically, of course, New Zealand's most vigorous literary debates have collectively focused on the need to articulate a distinctive national identity as rooted in place. This task, conventionally associated with the cultural nationalist writers of the 1930s, was at first an exclusively Pākehā and male reserve. From the second half of the 20th century, these restrictive literary gates finally opened to incorporate female, and then indigenous Māori voices. At the turn of the 21 st century, the limits of national literature continue to be pushed and redefined by authors of various Pacific and Asian backgrounds. However critical or subversive, these multicultural and diasporic authors still interpellate the nation as a central point of reference and the framework through which power relations are established and can be questioned. At the same time, it is also evident that these contested national definitions have historically operated in contrast or combination with supranational frameworks. In fact, besides its origins as a white settler colony, Aotearoa New Zealand is a bicultural nation, but also a Pacific country and a key player in the Asia-Pacific region. These multiple frameworks certainly overlap, resulting in a necessary "re-location of the literature in historical, regional and international terms" (Prentice 2003, 141).

Various critics have responded to the supposed incompatibility of global and local concerns explored in New Zealand fiction. In her discussion of the international impact of the works of Janet Frame and Elizabeth Knox, for instance, Janet Wilson (2004) talks about this writing as evidence that local or provincial elements "can be recontextualized and re-inflected through exposure in the international market place" 
(121), which in turn demonstrates New Zealand's "national interests [as] increasingly capable of being identified with global interests" (131). Similarly, Erin Mercer (2010) praises the performative character of work by writers like Eleanor Catton, Lloyd Jones or Paula Morris as evidence of their ability to leave behind former discussions of the colonial while engaging in a "quest for advantage in the globalized market" (102). Paula Morris (2015) has advocated demythologizing "New Zealand literature" as a closed entity that needs to be irremediably tied to place and rejects the idea that "a local focus is the writer's obligation" (71). Tim Corballis and Chris Price argue for the importance of recognizing that "the potential for 'our unique cultural identity' [may] be a straightjacket for some, while acknowledging its importance in many cases" $(2003,61)$. In this respect, it might be useful to take up Jennifer Lawn's (2016) suggestion that New Zealand writing should be perhaps conceived "in spatial terms as a cultural field, rather than in genealogical terms as $[\ldots]$ the outgrowth of a story of national self-realization and maturity" (8).

Considerations of how this "New Zealand story" has been told and the specific forces that come into play once these works "enter the world" must be made in the context of recent discussions on the commodification and marketing of postcoloniality (Huggan 2001, Brouillette 2007, Ponzanesi 2014). Besides unravelling the workings of this powerful global cultural industry and its articulation of the "postcolonial exotic" (Huggan 2001), these critics have also highlighted the strategies devised by writers to counteract its effects, ultimately aiming at the creation of "a new critical framework, or optic of analysis, through which the trajectory of the postcolonial artefacts is detected, accounted for and elaborated in its multiple functions" (Ponzanesi 2014, 47). The pull of the exotic has been more evidently noticeable in the case of Māori writers whose work is often, as Lydia Wevers points out, "inflected by a palette of perceived and 
marketable values from authenticity to spirituality" $(2004,114)$. In fact, Lawn remarks that New Zealand literature is "unique among settler-colonial literatures in that indigenous novels enjoyed canonical status from their earliest publication and [...] attract more global cachet" $(2016,7)$ than their Pākehā counterparts. This is true not only of authors like Keri Hulme, Patricia Grace and Witi Ihimaera, whose works have circulated widely in English and in translation, but also of filmic narratives like Lee Tamahori's Once Were Warriors (1994), based on Alan Duff's eponymous novel or Niki Caro's (2001) Whale Rider, adapted from Witi Ihimaera's (1987) novella The Whale Rider, internationally acclaimed precisely as a result of a local content which has obviously resonated with global tastes and interests.

A similar explanation of how the indigenous can gain global status bypassing the perceived constrains of the national is provided by James English (2005) in his analysis of Keri Hulme's the bone people (1983), the first New Zealand novel to obtain the Booker Prize in 1985. English argues that Hulme's novel, “celebrated at the subnational level of indigenous community $[\ldots]$ can now be fed directly into a global market for indigenous cultural production without any reference to a national standard of value" (272). Lydia Wevers, in fact, asks whether "globalization [allows] indigeneity a discourse which keeps it in place but frees it from the locking binaries of postcolonial nations" (2006, 121, original emphasis), concluding that many Māori writers manage to navigate the murky waters of postcolonial marketing by offering "a response to globalization and to postcolonialism that asserts cultural agency and recalibrates the relationship between global forces and the dynamics of locality, identity and culture" $(2006,129)$.

Apart from considerations of how "made in New Zealand" stories fare in the "blue skies of globalism" (Wevers 2004, 114), it is essential to turn our attention to how 
global economic forces have impacted on New Zealand soil, more specifically by looking at the effects of neoliberal and post-neoliberal (or "third way") policies in the country. Helen Clark's Fifth Labour Government (1999-2008) was a pioneer in reinforcing the connection between culture and national identity through state support and funding of the arts (Williams 2003, 16); likewise, this period was characterized by the state embracing the rhetoric of knowledge economy and reinforcing the links between economy and the creative industries. From 1999, when the highly successful “100\% Pure New Zealand” campaign was launched by Tourism New Zealand, the country's creative industries (most notably its film industry centralized in Wellington, or Wellywood, as it has come to be nicknamed) have been crucial to the consolidation of an exportable national brand through which the country's international profile has been enhanced. Jennifer Lawn argues in her book, Neoliberalism and Cultural Transition in New Zealand Literature 1984-2008, that "[b]y positioning creativity at the intersection of national identity, commerce, the arts, and subjectivity, government policies could knit together globalization and nationalism - discourses that in other contexts run counter to each other" $(2016,177)$.

The most striking example of this confluence is of course Peter Jackson's highly acclaimed The Lord of the Rings (2001-2003) and Hobbit films (2012-2014), repeatedly heralded as "New Zealand stories", despite being digitally enhanced versions of New Zealand landscapes with no local content. Nevertheless, and as Jones and Smith (2005) demonstrate, Jackson's projects embody “a new kind of New Zealand national identity, one which draws on traditional narratives of low-key but unique national ingenuity, while reworking them in terms of an emerging narrative of creative entrepreneurship" (924). It is ironic then that these internationally acclaimed narratives of local success, which have been so crucial to sanction the solid " $100 \%$ Pure" national brand, coexist 
with a literature which reflects increasingly dwindling national certainties, thus questioning earlier official discourses.

Discussing her participation as a writer in the 2012 Frankfurt International Book Fair, Paula Morris commented that she felt as if "we were there to undo the work of the New Zealand Tourist Board, which has been perhaps too successful in conveying the idea of our country as a blissful paradise, unspoiled and practically empty" $(2017,100)$. Morris's words point to the paradox of trying to reshape the cultural production of a small country through official channels of arts management by aiming to be more attuned to the global spheres. Despite all such attempts to reinflect the local culture with increasingly internationalized outlets, more prestigious modes of recognition, (e.g. prizes, awards, or festival appearances) and an accelerated circulation, it remains an enterprise largely driven by national considerations. This ongoing tension between global expectations and national frames of identification and aspiration is discussed by several contributors to this special issue. As argued in their different articles, contemporary New Zealand literature is being shaped in a continuum of creative practices and responses, with authors sometimes highlighting a culturally specific standpoint, playing for "Team NZ Lit", as Tim Corballis and Chris Price put it (2003, 61) or, by contrast, having a story located elsewhere and resisting being perceived as culturally specific. In that respect, it might be useful to share Lawn's preference for a bivalent approach, one which considers "how trends that appear to be fragmentary or contradictory may [...] be varying responses to a central, shared situation" $(2016,8)$, namely the ongoing struggle of New Zealand writers to find a voice locally as well as globally and a literary platform to articulate shared historical and cultural experiences.

Stefanie Herades's analysis of colonial New Zealand literature reflects on early struggles to accommodate these tensions between the local and the global. Herades 
offers an overview of the early colonial book trade, already global in nature, and the efforts of colonial writers to be published and read in their motherland, which reinforced the ongoing connections between colony and metropolis, but paradoxically also contributed to dismiss this literature as derivational and not worthy of integrating the national canon. Interestingly, Herades argues, these historical contingencies have also conditioned the scarce availability of colonial New Zealand literature in the global marketplace. Recent critical efforts directed at reassessing and validating these early works are now running parallel to the digitalization and commercialization of those texts in a range of global platforms, which is resulting in the expansion of the national canon.

Moving on to the contemporary context, even if keeping in mind the persistence and market value of old colonial tropes, Claudia Marquis and Paloma Fresno-Calleja consider popular fiction as a particularly useful platform from which to analyze the workings of the global postcolonial cultural industry. Marquis looks at David Hair's Aotearoa series for Young Adults and their construction of "the adolescent exotic", tracing the textual strategies employed by the author to position his books in the global marketplace. In the same line, and similarly departing from Huggan's formulation of the "postcolonial exotic", Fresno-Calleja discusses the historical romances of Sarah Lark, a German author whose landscape novels refashion old colonial tropes and settler renderings of history for European female readers more familiar with Middle Earth than with Māoriland. It is interesting that, despite the writers' different backgrounds, the texts seem to converge in an exoticised global space catering for adepts of the "exotic". Conversely, James Wenley's discussion of the work of the Indian Ink theatre company explains its ongoing success due to the ability of its founder-directors, Jacob Rajan and Justin Lewis, to tell universal stories rather than stories defined by a specific 
nationality. In fact, Wenley ascribes the success of the company to the skill of its creative partners in creating exportable plays, moving away from a transnational New Zealand-Indian focus towards a more global orientation.

These different preferences are also discussed in connection to practices of translation and tertiary teaching. Janet M. Wilson examines the contemporary short story by considering the first translation into Spanish of a selection of iconic stories from Aotearoa New Zealand. The stories in Un Pais de Cuento combine a canonical national imaginary based on representations of place, identity and culture with globally oriented stories that show the impact of creative writing programmes, and reflect the hypermobility of the contemporary era, bypassing the questions about national identity that dominated earlier stories to explore global paradigms offered by the social media and new literature platforms, or engage with transnational experiences of estrangement, alienation, or (un)belonging. In her contribution, Chris Prentice examines the globalization of tertiary education in Aotearoa New Zealand as recruitment of students from overseas educational markets has accelerated. Noting how the binary between local and global is being broken down by a plethora of global perspectives, Prentice uses Derrida's trope of the parergon to investigate how nationalistic framings of undergraduate "New Zealand Literature" courses are being disturbed by changed expectations of local students with global bearings, as well as increasingly ethnically diverse students from overseas.

The selection of articles is followed by contributions from Paula Morris and Dieter Riemenschneider which explore two crucial events for the internationalization of New Zealand literature in the last decade: the 2012 Frankfurt Book Fair where New Zealand was chosen as Guest of Honour, and the choice of Eleanor Catton's The Luminaries as Booker Prize winner in 2013. Departing from his academic experience in 
Germany, one of the European countries where New Zealand literature and culture is most appreciated, Riemenschneider's “On Sale: Aotearoa New Zealand Literature in Germany" comments on the two interrelated processes of "selling" or "translating". The measures the actual impact of the Frankfurt Book Fair in terms of the translation and popularization of New Zealand literature among German readers. These reflections move to the academic context, where Riemenschneider ponders on the strategies of translation and intercultural understanding that are at stake in the process of teaching New Zealand literature. For her part, Paula Morris considers the workings of the global prize industry by looking at the marginalization of Commonwealth writers, and in particular the fate of New Zealand authors in the history of the Booker Prize. Morris condemns the neo-imperial nature of the prize and the restrictive rules that the global publishing industry still imposes on writers from Commonwealth countries, suggesting the perdurability of old imperial hierarchies.

The issue continues with the editors' interview with Selina Tusitala Marsh, the first person of Pacific descent to receive the New Zealand's Poet Laureateship (20172019). This conversation took place after Marsh successfully co-hosted the Triennial Conference of the Association for the Study of Commonwealth Literatures and Languages (ACLALS) at the University of Auckland (July 2019). This was a major international academic gathering devoted, among other things, to discuss New Zealand's position in this "uncommonly flexible set of social, political, legal and economic forms of association" (aclals.auckland.ac.nz). Marsh's career and her term as Poet Laureate has been crucial to incorporate the Pasifika perspective into the national poetry canon, while showcasing Aotearoa New Zealand poetry to the world, a task that she describes at length alongside discussion of her upbringing, her literary influences, 
her role as an academic and a poet, as well as the symbolic significance of her tokotoko, the Māori ceremonial walking-stick gifted to New Zealand Poets Laureate.

Finally, and on a fitting note to conclude this special issue, "New Zealand Literature and Globalization", is a review article by Chris Miller of works by and about the New Zealand poet, Allen Curnow, who died in 2001: the long awaited, posthumously-published biography by Terry Sturm, Allen Curnow. Simply by Sailing in a New Direction. A Biography, and Allen Curnow: Collected Poems, edited by Elizabeth Caffin and Terry Sturm, both issued by Auckland University Press. For long New Zealand's most distinguished poet and an influential advocate of cultural nationalism, Curnow dramatically internationalized his poetic orientation in a radical mid-life refashioning with the publication of Trees, Effigies, and Moving Objects (1972). This review essay is a complement to "Remembering Curnow", a special issue of the Journal of New Zealand Literature, proceedings of a symposium held at the University of Auckland in 2017 to mark the publication of these companion volumes (Calder 2019), but it will by no means be the last word on this epoch-shaping writer. Collectively these articles by scholars and writers from European and New Zealand universities examine the cultural production of a location where globalization has sparked serious reflection on the original project of cultural nationalism. The aim of this issue is to encourage a reconfiguring of forms of representation both within and beyond the nation and a reshaping of the national imaginary: New Zealand's natural assets continue to be reimagined and commodified, both within and outside the country, in genres like imperial romance and the visual media that are intrinsically "global" and inspire multiple cultural and linguistic translations. Yet in genres that were in the 20th century seminal for New Zealand identity - like short fiction, the novel and drama- the process of reinterpretation continues, as the question of New Zealandness comes under 
pressure of the global, and landscape, place, action and character are delinked from a provincial nationalism. Global forces have an uneven purchase in Aotearoa New Zealand, yet as they continue to permeate all levels of society, contemporary writers, artists and academics are motivated to develop aesthetic and narrative strategies to represent the transnational consciousness that is increasingly adept at cross border travel. The new pedagogies, artistic practices and creative formats visible in the textual practices of these artists, show the experience of living in a southern far flung island nation and carry their own particular inflection in response to the planetary conditions that affect lives everywhere in the $21^{\text {st }}$ century.

\section{References}

Ashcroft Bill, 2013. "Beyond the Nation: Australian Literature as World Literature.” In Scenes of Reading: Is Australian Literature a World Literature?, edited by Rob Dixon and Bridget Rooney, 34-46. Melbourne: Australian Scholarly Press.

Bhabha, Homi K. 1994. The Location of Culture. London: Routledge.

Bhabha, Homi K. 1990: Nation and Narration. London: Routledge.

Brah, Avtar 1997. Cartographies of Diaspora: Contesting Identities. London: Routledge.

Brouillette, Sarah. 2007. Postcolonial Writers in the Global Literary Marketplace. Basingstoke: Palgrave.

Calder Alex, ed. 2019. "Remembering Curnow." Special issue of Journal of New Zealand Literature 37 (2)

Campion, Jane, dir. 1993. The Piano. Woollahra NSW: Jan Chapman productions. Caro, Niki, dir. 2002. Whale Rider. South Pacific Pictures. 
Casanova, Pascale. 2004. The World Republic of Letters. Cambridge, MA: Harvard University Press.

Catton, Eleanor. 2013. The Luminaries. London: Granta.

Cheah, Pheng. 2016: What is a World? On Postcolonial Literature as World Literature. Durham, NC: Duke University Press.

Cheah, Pheng, and Bruce Robbins, eds. 1998. Cosmopolitics: Thinking and Feeling Beyond the Nation. Minneapolis, MN: University of Minnesota Press.

Corballis, Tim and Chris Price. 2004. "Writing That Matters: Two Views of the Place of Politics in Literature." In Writing at the Edge of the Universe, ed. Mark Williams, 49-67. Christchurch: Canterbury University Press.

Curnow, Allen, 1972. Trees, Effigies, and Moving Objects: A Sequence of Poems. Wellington: Catspaw Press.

Damrosch, David. 2003. What is World Literature? Princeton, NJ: Princeton University Press.

Duff, Alan. 1990. Once Were Warriors. Auckland: Tandem Press.

English, James F. 2005. The Economy of Prestige. Prizes, Awards and the Circulation of Cultural Value. Cambridge, MA: Harvard University Press.

Evans, Patrick. 2007. The Long Forgetting. Post-Colonial Literary Culture in New Zealand. Christchurch: Canterbury University Press.

Evans, Patrick. 2000. "Spectacular Babies: The Globalisation of New Zealand Fiction." World Literature Written in English 38 (2): 94-109.

Gilroy, Paul. 1993. The Black Atlantic and Modernity as Double Consciousness. Cambridge, MA: Harvard University Press.

Helgesson, Stephan. 2014. "Postcolonialism and World Literature. Rethinking the Boundaries.” Interventions 16 (4): 483-500. 
Helgesson, Stefan and Pieter Vermeulen. 2016. "Introduction: World Literature in the Making.” In Institutions of World Literature: Writing, Translation, Markets, edited by Stefan Helgesson and Pieter Vermeulen, 1-20. London: Routledge. Huggan, Graham 2001. The Postcolonial Exotic. Marketing the Margins. London: Routledge.

Hulme, Keri. 1983. the bone people. Wellington: Spiral.

Ihimaera, Witi. 2015. Where is New Zealand Literature Heading? A New Zealand Book Council Lecture. Wellington: New Zealand Book Council.

Ihimaera, Witi. 1987. The Whale Rider. Auckland: Heinemann.

Jackson, Peter, dir. 2001-2003. The Lord of the Rings. New Line Cinema and WingNut Films.

Jackson, Peter, dir. 2012-2014. The Hobbit. WingNut Films, New Line Cinema, MetroGoldwyn-Mayer.

Jones, Deborah and Karen Smith. 2005: "Middle-Earth Meets New Zealand: Authenticity and Location in the Making of The Lord of the Rings." Journal of Management Studies 42 (5): 923-945.

Lawn, Jennifer. 2016. Neoliberalism and Cultural Transition in New Zealand Literature 1984-2008. Market Fictions. New York: Lexington Books.

Mercer, Erin. 2010. “As Real as the Spice Girls: Representing Identity in Twenty-first Century New Zealand Literature.” Journal of New Zealand Studies 9: 99-114. Moretti, Franco. 2000. “Conjectures on World Literature.” New Left Review 1: 54-68. Morris, Paula. 2015. On Coming Home. Wellington: Bridget Williams Books. Morris, Paula. 2016. "Do New Zealand Books Need Special Treatment?” http://trendybutcasual.typepad.com/trendy_but_casual/books/. 20 September 2016 (accessed June 2017). 
Morris, Paula. 2017. “Of All Places: A Polemic on 'International' Book Prizes.” Ora Nui. Maori Literary Journal 3: 96-103.

Newton, John. 2017. Hard Frost. Structures of Feeling in New Zealand Literature. 1908-1945. Wellington: Victoria University Press.

Ponzanesi, Sandra. 2014. The Postcolonial Cultural Industry: Icons, Markets, Mythologies. Basingstoke: Palgrave.

Prentice, Chris. 2003. “Critical Transformations: New Zealand Literary and Cultural Studies." AUMLA: Journal of the Australasian Universities Modern Language Association 100: 134-146.

Quayson, Ato, and Girish Daswani, eds. 2013: A Companion to Diaspora and Transnationalism. Oxford: Wiley Blackwell.

Tamahori, Lee, dir. 1994. Once Were Warriors. Fine Line Features.

Wevers, Lydia. 2004. "The Politics of Culture”. In Writing at the Edge of the Universe, edited by Mark Williams, 109-122. Christchurch: Canterbury University Press.

Wevers, Lydia. 2006. “Globalising Indigenes: Postcolonial Fiction from Australia, New Zealand and the Pacific.” JASAL 5: 121-132.

Williams, Mark. 2004. "Introduction". In Writing at the Edge of the Universe, edited by Mark Williams, 7-19. Christchurch: Canterbury University Press.

Wilson, Janet. 2004: “New Zealand Literary Nationalism and the Transcultural Future. Or: Will the Centre Hold?" In Towards a Transcultural Future. Literature and Society in a "Post"-Colonial World, edited by Geoffrey Davis, Peter H. Marsden, Bénédicte Ledent and Marc Delrez, 119-134. Amsterdam: Rodopi.

Young, Robert C. 2012. "World Literature and Postcolonialism." In The Routledge Companion to World Literature, edited by Theo D'haen, David Damrosch, and Djelal Kadir, 213-222. London: Routledge. 


\section{Acknowledgements}

Paloma Fresno-Calleja gratefully acknowledges the financial support of the Spanish Ministry of Economy, Industry and Competitiveness (MINECO), the Agencia Estatal de Investigación (AEI) and the European Regional Development Fund (ERDF) (Reference FFI 2016-75130-P).

\footnotetext{
${ }^{1}$ It first appeared in the newsletter Kite 22 (2002), 5-14, was expanded and published in World Literature Written in English (renamed as Journal of Postcolonial Writing) in 2003 (the journal date is 2000 but in fact its publication lagged three years behind the year), and later that year in shortened form in The New Zealand Listener (August 16, 2003). Finally, Evans summarised his arguments in The Long Forgetting (2007).

${ }^{2}$ Most of the articles included in this special issue originated as presentations delivered at the "Islands for Sale Conference: New Zealand and Pacific Arts in the Global Marketplace" (June 29 to July 1, 2017) at Regent's University in London, co-hosted by the University of Northampton and Te Kāhui Rangahau Kōrero mō Aotearoa - the New Zealand Studies Network.
} 